NBER WORKING PAPER SERIES

\title{
THE ECONOMICS OF LABOR MARKET INTERMEDIATION: AN ANALYTIC FRAMEWORK
}

\author{
David H. Autor \\ Working Paper 14348 \\ http://www.nber.org/papers/w14348 \\ NATIONAL BUREAU OF ECONOMIC RESEARCH \\ 1050 Massachusetts Avenue \\ Cambridge, MA 02138 \\ September 2008
}

The twelve papers in this volume were prepared for and presented at the NBER Conference on Labor Market Intermediation in May of 2007, and are forthcoming as Studies of Labor Market Intermediation from the University of Chicago Press. The Labor Market Intermediation conference and resulting volume were generously supported by the National Bureau of Economic Research and the National Science Foundation (CAREER award SES-0239538). I am particularly grateful to James Poterba, Marty Feldstein and Richard Freeman for their intellectual guidance and moral support in the development of this endeavor. In addition, David J. Pervin of the University of Chicago Press, Helena Fitz-Patrick of NBER, and two anonymous referees provided invaluable input on the manuscript. I finally thank Carl Beck of NBER for his superb coordination of all aspects of the conference. The views expressed herein are those of the author(s) and do not necessarily reflect the views of the National Bureau of Economic Research.

NBER working papers are circulated for discussion and comment purposes. They have not been peerreviewed or been subject to the review by the NBER Board of Directors that accompanies official NBER publications.

(C) 2008 by David H. Autor. All rights reserved. Short sections of text, not to exceed two paragraphs, may be quoted without explicit permission provided that full credit, including $\odot$ notice, is given to the source. 
The Economics of Labor Market Intermediation: An Analytic Framework

David H. Autor

NBER Working Paper No. 14348

September 2008

JEL No. J4,J5,J6

\begin{abstract}
$\underline{\text { ABSTRACT }}$
Labor Market Intermediaries (LMIs) are entities or institutions that interpose themselves between workers and firms to facilitate, inform, or regulate how workers are matched to firms, how work is accomplished, and how conflicts are resolved. This paper offers a conceptual foundation for analyzing the market role played by these understudied institutions, and to develop a qualitative and, in some cases, quantitative sense of their significance to market operation and welfare. Though heterogeneous, I argue that LMIs share a common function, which is to redress -- and in some cases exploit -- a set of endemic departures of labor market operation from the efficient neoclassical benchmark. At a rudimentary level, LMIs such as online job boards reduce search frictions by aggregating and reselling disparate information at a cost below which workers and firms could obtain themselves. Beyond passively supplying information, a set of LMIs forcibly redress adverse selection problems in labor markets by compelling workers and firms to reveal normally hidden credentials, such as criminal background, academic standing, or financial integrity. At their most forceful, LMIs such as labor unions and centralized job matching clearinghouses, resolve coordination and collective action failures in markets by tightly controlling -- even monopolizing -- the process by which workers and firms meet, match and negotiate. A unifying observation of the analytic framework is that participation in the activities of a given LMI are typically voluntary for one side of the market and compulsory for the other; workers cannot, for example, elect to suppress their criminal records and firms cannot opt out of collective bargaining. I argue that the nature of participation in an LMI's activities -- voluntary or compulsory, and for which parties -- is dictated by the market imperfection that it addresses and thus tells us much about its economic function.
\end{abstract}

David H. Autor

Department of Economics

MIT, E52-371

50 Memorial Drive

Cambridge, MA 02142-1347

and NBER

dautor@mit.edu 
Labor Market Intermediaries (LMIs) are entities or institutions that interpose themselves between workers and firms to facilitate, inform, or regulate how workers are matched to firms, how work is accomplished, and how conflicts are resolved. In the textbook competitive model of the labor market, LMIs do not exist-nor is there any need for them. If information is complete and markets are competitive, theory suggests that decentralized, atomistic labor markets are hard to improve upon.

Economists have long recognized that labor markets deviate substantially from this neoclassical benchmark. Sumner Slichter (1950) observed more than fifty years ago that the 'law of one price' did not appear to hold in labor markets; seemingly identical workers earned markedly different wages depending upon what industry they labored in.1 H. Greg Lewis demonstrated in the 1970s that membership in a labor union conferred substantial wage benefits, underscoring that atomistic wage-setting is far from universal. Akerlof (1970) showed that a small amount of private information in markets may be sufficient to thwart trade entirely. Shortly thereafter, Spence (1973) identified a set of conditions under which employers might reward workers for acquiring costly credentials that have no productive value. During the 1980s, Diamond, Mortensen and Pissarides formalized the observation that decentralized labor market search typically leads to a market equilibrium with both unfilled jobs and unemployed workers.2 This body of theory and evidence suggests that labor market information is not usually complete or symmetric, workers are not typically commodities, firms are not always price takers, and in general, there may be scope for third parties_Labor Market Intermediaries, in particular - to intercede both to improve the operation of the labor market and to profit from its imperfections.

The goal of this volume is to offer a conceptual foundation for analyzing the roles that these understudied economic actors play in the labor market, and to develop a qualitative and, in some cases, quantitative sense of their significance to market operation and worker welfare. The twelve papers in this volume, prepared for and presented at the NBER Conference on Labor Market Intermediation in May of 2007, offer novel

\footnotetext{
1 This finding was corroborated by, among others, Krueger and Summers (1988) and Katz and Summers (1989).

${ }^{2}$ Diamond (1982), Mortensen (1982), Pissarides (1986).
} 
empirical analyses of a diverse array of LMIs, including online job search engines, criminal records providers, public employment offices, state regulatory bodies, labor unions, centralized job matching markets, and temporary help agencies. Although heterogeneous, a central theme of this volume is that these intermediaries serve a common role, which is to address a set of endemic departures of labor market operation from the neoclassical benchmark. The intellectual challenge taken up by the volume is to identify and systematically classify these departures, and to consider how market and non-market actors - workers, firms, public officials, non-governmental organizationsadapt to them to improve or to exploit the decentralized outcomes that result.

The parsimonious and (I hope) encompassing taxonomy offered by this introductory chapter highlights three major deviations of labor market operation from the neoclassical benchmark and considers how LMIs potentially address - and in some cases exploit them. These deviations are costly information, adverse selection, and (failures of) collective action. This chapter develops this three-part taxonomy and uses it to illustrate the underlying economic forces that connect the twelve papers in the volume. A unifying observation that emerges is that participation in the activities or services of a given LMI are typically voluntary for one side of the market — workers or employers — and compulsory for the other. I argue that this pattern of voluntary and compulsory participation is largely dictated by the nature of the market imperfections that LMIs address, and thus can tell us much about the roles that intermediaries play in the market. Figure 1, which categorizes LMIs by market function and the nature of worker and firm participation (voluntary/compulsory) in their activities, provides a roadmap to the main arguments of the chapter.

\section{Costly information}

In the benchmark neoclassical model of the labor market, it is costless for workers and firms to search for each other. In reality, search is costly. Workers pay directly for search, through the monetary and psychic costs of applying and interviewing for jobs, and indirectly, through foregone work or leisure. Employers likewise incur search costs directly, through help-wanted advertising, job fairs, and applicant screening and interviewing, and indirectly through foregone output while vacancies await workers. 
Since information about job vacancies and job-seekers is in large part a public good—in particular, each firm would like to be aware of all job-seekers, and each job-seeker would like to be aware of all vacancies - this information is likely to be under-supplied by the market.

The first chapters of this volume portray a set of LMIs that serve as 'informationonly' intermediaries - entities whose near-exclusive function is to aggregate, package and sell information about job-seekers and job vacancies. The leading example of an information-only intermediary is the online job board, which serves as a clearinghouse for workers seeking jobs and jobs seeking workers. The chapter by Nakamura, Shaw, Freeman, Nakamura and Pyman provides an analytic perspective on how the business of online job search functions - how firms use it, how workers use it, and how online search firms profit from the process.

While at their most basic level, job boards merely post lists of job-seekers and job vacancies, Nakamura et al. outline how the business of online job boards has evolved greatly from this rudimentary help-wanted function. Large job boards, like Monster.com, CareerBuilder.com, and Hotjobs.yahoo.com, increasingly provide an outsourced personnel recruitment function for large employers, hosting the employment sections of their corporate web sites, contacting potential candidates en masse, accepting and prescreening resumes, tracking applications, and providing access to an exclusive set of candidates - for example, students of elite universities given privileged access to these sites as they near the completion of their studies. ${ }^{3}$ A key point made by Nakamura et al. is that, by making it easier for employers to identify potential candidates among those currently employed ('passive seekers') and simultaneously lowering workers' costs of engaging in on-the-job search, job boards may particularly advantage employed relative to non-employed job-seekers. ${ }^{4}$

The chapter by Stevenson complements this analytic overview by providing an initial empirical analysis of how the Internet may be changing job search behavior in the United States. Stevenson documents that the variety of job search methods used by unemployed

\footnotetext{
${ }^{3}$ A related paper by Kroft and Pope (2007) provides evidence on the degree to which online job engines, Craigslist in particular, have displaced the traditional newspaper help-wanted business.

${ }^{4}$ A 2004 paper by Kugler and Saint Paul considers how the imposition of firing costs in the presence of worker adverse selection differentially disadvantages non-employed relative to employed job-seekers.
} 
U.S. workers has increased significantly over the last decade, coincident with the rapid rise in Internet penetration. Moreover, in U.S. states where Internet penetration has risen the most, the unemployed appear increasingly likely to use job advertisements for seeking and contacting employers directly—suggesting that online and offline search may be complements. Consonant with the observations by Nakamura et al., Stevenson shows that the vast majority of workers using the Internet to gather information about employment are those who are already employed. Logically, workers who use the Internet for job search are more likely to leave their current employer. It is plausiblethough far from certain — that online job search may increase the rate at which workers change jobs. ${ }^{5}$

\section{Mitigating adverse selection}

While pure 'information-only’ intermediaries address an important public goods problem, this category of LMI is relatively narrow and, I would argue, less consequential than the bulk of the LMIs discussed below. The reason is that where information is costly, the central economic problem is typically not exclusively costly information but also asymmetric information. Specifically, if information about the quality of workers or jobs is incomplete, better-informed market actors have an incentive to exploit their informational advantage to the detriment of less-informed market actors. As first outlined by Akerlof (1970), these information asymmetries readily generate a market equilibrium where lower quality market actors (workers or firms) exert negative externalities on their higher quality counterparts, depressing both the quantity and quality of trade.

While job boards might appear to offer a powerful mechanism to bolster aggregate labor market efficiency, qualitative and quantitative evidence suggests that job boards do not reach this potential. An analysis of U.S. job search data by Kuhn and Skuterud (2004) finds that workers who use the Internet to search for jobs fare no better-and perhaps worse - than observably similar workers who do not search for jobs using the Internet. Their analysis suggests that either Internet job search is ineffective at reducing

\footnotetext{
${ }^{5}$ If the Internet provides incumbent workers with better information about their outside opportunities, these workers do not need to change jobs to benefit. Web sites like greedyassociates.com, for example, which publicize the salary offers made to newly minted attorneys, may serve to homogenize the distribution of law firm associate wages.
} 
unemployment durations or Internet job searchers are negatively selected on unobservables. One recruiting executive, quoted in Autor (2001b), lends informal support to the latter hypothesis, asserting that job boards are populated by four adversely selected pools: "The unhappy (and thus probably not a desirable employee); the curious (and therefore likely to be a 'job-hopper'); the unpromotable (probably for a reason); and the unemployed (probably for a worse reason).”

The core problem facing job boards - reflected in the above quotation - is that workers posting their resumes and credentials online face a strong incentive to conceal or slant information to make themselves more attractive to potential employers. Recognizing this, employers are likely to treat information posted to job boards with skepticism. If in equilibrium, employers view the information on job boards as untrustworthy, these boards can do little more than provide employers with names and numbers, leaving them to discover essential information about worker skills and qualifications through other mechanisms such as interviews, background checks, and job references.

A natural solution to this asymmetric information problem is compulsory disclosure; if job-seekers can be compelled to reveal information that they would not necessarily disclose voluntarily, this could substantially improve the efficiency of job search and matching - though clearly not all workers would benefit. Though compulsory disclosure sounds difficult to achieve in real world labor markets, Chapters 3 and 4 study two Labor Market Intermediaries that perform exactly this function: reducing worker-side adverse selection by, implicitly or explicitly, compelling job applicants to reveal information that they might otherwise conceal.

A key piece of information that employers may seek to ascertain is criminal history. As Chapter 3 by Keith Finlay reveals, almost 20 percent of black males and more than 10 percent of white males in recent U.S. youth cohorts have been incarcerated by age 24 . Historically, criminal background checks have been comparatively expensive to perform, and not particularly reliable. Between 1998 and the present, however more than a dozen US states placed their criminal history records databases online for use by employers and other interested parties. Implicitly, job-seekers applying for jobs in 'open records' states are now compelled to submit to a criminal background check at the employer's 
discretion. The opening of criminal records therefore functions as a publicly operated LMI that may in theory reduce worker-side adverse selection.

How does this opening affect labor market operation in practice? Working from a simple statistical discrimination framework, Finlay hypothesizes that if employers do not initially observe applicants' criminal histories and instead attempt to infer them based on other observable characteristics (such as education, age, gender and race), the opening of criminal records should diminish the labor market prospects of ex-offenders while potentially benefiting non-offenders who might otherwise be viewed as potential criminals. Using data from the National Longitudinal Study of Youth 1997 Cohort, Finlay finds support for the first proposition. Young adults with criminal histories face reduced employment odds and lower wages after states make criminal histories available online. There is less evidence, however, that young adults without criminal records who appear demographically similar to potential criminals fare better once criminal records are opened. This result may indicate that employers underestimate the prevalence of criminality in the absence of open criminal records - and hence, opening of criminal records impedes applicants who are revealed to be offenders without benefiting those who are revealed to be non-offenders. As Finlay cautions, however, the relatively small NLSY 97 sample provide insufficient power to detect the diffuse benefits hypothesized to accrue to the non-offender population. What appears unambiguous is that opening of criminal records does diminish the labor market prospects of ex-offenders.

Although both online job postings and online criminal records potentially serve to reduce search costs in labor markets, the crucial distinction between these LMIs from the perspective of this chapter lies in the nature of information disclosure. Users of job boards may reveal, disclose or simply fabricate information at will. Job applicants in 'open records' states have no say in whether their criminal backgrounds are made publicly available. It appears plausible that this distinction explains why open records have real bite: they credibly supply information about worker credentials that applicants might otherwise conceal

The chapter by Bagues and Labini studies an unusual job search engine, AlmaLaurea, which also has this compulsory revelation feature. Founded in 1994 by an inter-university consortium of Italian universities, AlmaLaurea was set up to increase the frequency of 
successful school-to-work transitions among Italian university graduates, which have been astonishingly low in recent decades. What distinguishes AlmaLaurea from most electronic job boards it that it provides detailed administrative records on participants' courses of study, grades obtained and rank in class. Moreover, it provides this information for almost the entire set of students currently graduating from the universities in the consortium. In effect, AlmaLaurea offers the university equivalent of 'open records’ for job applicants: a college transcript, a class ranking, and, implicitly, a comparison of each applicant to his immediate peers.

A thoroughgoing empirical analysis by Bagues and Labini offers compelling evidence that AlmaLaurea reduced the non-employment rate of graduates of AlmaLaurea member universities. Specifically, comparing changes in the non-employment rate of graduates of universities joining AlmaLaurea over 1998 to 2001 relative to graduates of universities that had not yet joined during this period suggests that AlmaLaurea reduced the nonemployment rate of AlmaLaurea graduates by several percentage points-which is considerable. Because Italian labor market conditions were rapidly improving during the time period studied, there is room for concern that the difference-in-difference approach employed might be unreliable. Bagues and Labini do much to allay this concern, including conducting placebo tests of the AlmaLaurea 'treatment' in the pre-treatment period, and exploiting a second wave of AlmaLaurea roll-outs to confirm the main finding.

The AlmaLaurea study leaves open two questions that subsequent research will want to address. First, did the reduction in unemployment of AlmaLaurea graduates come in part at the expense of other potential workers? Intuition might suggest yes, but initial analysis by Bagues and Labini suggests otherwise. Alternatively, if AlmaLaurea primarily expanded the total employment roster, what does this imply about the magnitude of search costs or adverse selection in the Italian labor market absent AlmaLaurea? A second question ripe for study is whether AlmaLaurea resulted in a redistribution of opportunities among job candidates within member institutions. Since AlmaLaurea was built to facilitate direct comparisons among candidates from member universities, it is plausible that it produced both winners and losers-improving 
opportunities for the most distinguished students and reducing them for the least distinguished. ${ }^{6}$

Adverse selection is not of course limited to the worker side of the labor market. Firms may equally face incentives to exploit asymmetric information to the detriment of workers and customers. The chapter by Woong Lee confronts the problem of adverse selection of firms, in particular, firms that are themselves LMIs. Lee's chapter provides an original empirical analysis of the rise of US Public Employment Offices (PEOs) at the turn of the $20^{\text {th }}$ century. At that time, the services of private, for-profit employment agencies were widely sought by job-seekers, particularly by unskilled workers and migrants. The lack of sophistication of these job-seekers, however, left them vulnerable to exploitation. Some of the abuses perpetrated by for-profit employment agencies included sending job-seekers to distant locations where no work existed, colluding with employers to provide applicants with only temporary work stints followed by summary discharge, and (occasionally) sending unwitting female job-seekers to brothels. Thus, forprofit employment agencies appear to have heavily exploited precisely the information asymmetries they were hired to resolve.

For U.S. state governments facing this predicament, several remedies were conceivable, including regulating and licensing for-profit employment agencies or banning them outright. The approach pursued by the states, however, was ingenious. Rather than attempting to directly curtail the behavior of abusers, states chose to effectively compete them out of business by offering high quality employment assistance services at Public Employment Offices at no cost to job-seekers. This response seems to reflect a pinpoint diagnosis of the market failure and its remedy. By introducing competition between for-profit LMIs and reputable public sector LMIs, states likely drove many of the lowest-quality PEOs out of business. What was left behind, presumably, were PEOs thatoffered sufficient value-added to justify a positive price despite the presence of a reputable, zero-cost competitor.

The chapter by Dick Todd and Morris Kleiner considers another example of a public response to a perceived failure of intermediation, in this case by mortgage brokers.

\footnotetext{
${ }^{6}$ This outcome would also be consonant with the reasoning of the Finlay study.
} 
Mortgage brokers are for-profit agents (individuals of firms) that match potential mortgage borrowers with lenders and assist borrowers in completing the loan origination process. These brokers were insignificant in the mortgage market in 1980, but by 2004 were involved in approximately 68 percent of all mortgages originated. Coinciding with their rapid growth was a rise in public concern that market failures prevented competition from effectively disciplining brokers' quality of service. ${ }^{7}$ As mortgage brokering grew, numerous states passed laws requiring brokers to post surety bonds or maintain a minimum net worth in order to operate. These requirements potentially work to ensure that borrowers have financial recourse if brokers are malfeasant. In addition, because sellers of surety bonds would be expected to charge risky brokers a higher price, bonding requirements create an entry barrier that is potentially more onerous for low than high quality mortgage brokers.

Consistent with this reasoning, Kleiner and Todd show that bonding requirements reduced mortgage broker employment, curtailed subprime loan originations and increased the observed qualification levels (measured by education and experience) of brokers operating in the mortgage broker occupation. Interestingly, however, Kleiner and Todd also find that bonding requirements increased mortgage foreclosure rates and raised the probability that newly originated loans were high-priced relative to other loans with similar characteristics. While Kleiner and Todd advise appropriate caution in interpreting these adverse impacts, they note that they are consistent with the influential arguments of Friedman (1962) that occupational licensing requirements dampen market discipline and produce artificial scarcity, leading to higher fees for providers and lower quality for consumers. $^{8}$

While mortgage brokers are arguably product market rather than labor market intermediaries, they have much in common with the for-profit employment offices studied by Woong Lee. Both employment offices and mortgage brokers serve to match individuals on one side of the market (workers or borrowers) to sellers on the other side (employers or mortgage lenders). The role played by these intermediaries is a natural

\footnotetext{
${ }^{7}$ This concern was exacerbated by the fact that mortgage brokers dominated the origination of so-called subprime mortgages - that is, loans to borrowers who would not be considered creditworthy by traditional lending standards.

${ }^{8}$ For an extensive treatment of this topic, see Kleiner’s (2006) monograph on occupational licensing.
} 
market response to the problem posed by costly search. There is, however, an adverse selection problem that intrinsically arises in this setting: intermediaries that are in the business of selling information are, by nature, better informed about information they sell than are the customers they serve. A wealth of theory and evidence suggests that markets are unlikely to operate optimally when sellers and buyers are not equally informed. As the chapters by Lee and Kleiner and Todd suggest, some subset of intermediaries will use their informational advantage to exploit rather than to assist customers.

These parallels suggest some general lessons on the mixed role that intermediaries play in reducing information costs in labor markets. Since the public good of labor market information is likely to be underprovided by the free market, a set of LMIS will find it profitable to collect and sell information at a cost below that which job-seekers could obtain by their own efforts. These intermediaries mitigate the under-provision problem. But their informational advantage also potentially gives rise to another market failure, which is information asymmetry and the attendant risk of adverse selection. Whether this asymmetric information problem is moderate or severe depends in part on the market structure in which intermediaries operate. In the case of private employment agencies at the turn of the $20^{\text {th }}$ century, these abuses were apparently profound. But a change in market structure, fostered by competition between public and private-sector providers substantially mitigated the problem. In the case of mortgage brokers, it is less certain that the regulatory remedy_creating barriers to entry_-provided the structural change needed.

In both cases, it is significant that the policy response to adverse selection included forcible public intervention in the market: an injection of competition in the case of Public Employment Offices; the imposition of bonding requirements in the case of mortgage brokers. These examples reinforce the general observation that, to address significant market imperfections, LMIs must be capable of changing the incentives faced by at least one set of market agents, typically workers or firms.

\section{III.Solving collective action problems}

Providing information-even compelling it—is not necessarily sufficient to resolve market failures. Notifying a bank's deposit holders that the institution faces a small risk 
of insolvency does not make a run on the bank less likely-rather, it spurs each depositor to withdraw his funds, thus ensuring collapse. In such cases, rational agents acting with full information and accurate expectations about one-another's actions make decisions that are privately optimal yet collectively suboptimal. There is potential in such settings for market intermediaries to improve upon competitive outcomes. But this is only feasible if these intermediaries have teeth—or, more specifically, the power to change payoffs so that the maximizing choices of actors on one or both sides of the market also serve the common good.

The chapters by Muriel Niederle and Alvin Roth and by Richard Freeman and Marit Rehavi consider two such intermediaries. Niederle and Roth analyze the labor market for medical fellowships (post-residency training) in the specialty of gastroenterology. Unraveling is widespread in entry-level labor markets for highly specialized positions, including legal clerkships and medical specialties. Candidates in these fields often sign binding employment contracts one or more years prior to the start of work-well before the quality of job matches can be reliably assessed. And job offers are frequently made with short ('exploding') decision deadlines and substantial professional penalties for reneging. The allocative efficiency of such a matching process is likely to be poor.

The Niederle and Roth chapter offers a diagnosis of the market failures in entry-level specialty markets and a quantitative analysis of how these problems were manifest and subsequently resolved (at least for some time) by the LMI of a centralized fellowship match. Niederle and Roth argue that the underlying cause of market unraveling is congestion. In occupations where most entry-level candidates enter the labor market simultaneously (i.e., as a cohort completes its studies), there is typically insufficient time for employers to evaluate and make offers to all relevant candidates before competing offers have already been made and accepted. This congestion spurs employers to make time-limited (exploding) offers to candidates to reduce the risk that, should their initial offers be declined, they are left to hire from the residual candidate pool. When exploding offers become commonplace, employers quickly recognize that they can employ them strategically to make job markets artificially 'thin' for their preferred candidates. Specifically, by forcing a candidate to make a binding decision before her alternative offers are known, an exploding offer turns the candidate's simultaneous decision problem 
into a sequential decision problem. Such strategies naturally lead to unraveling: anticipating that their competitors will make exploding job offers, each employer has an incentive to accelerate its own offers.

A primary implication of Niederle and Roth's diagnosis is that market unraveling could potenetially be checked if job offers were effectively delayed (or made nonbinding) until candidates and employers had sufficient time to search over their relevant choice sets. The National Resident Matching Program (NRMP), studied by Niederle and Roth, performs this function. The NRMP provides a centralized clearinghouse where applicants and employers submit rank ordered lists representing their preferences. Applying a set of deferred acceptance algorithms, the NRMP allocates candidates to fellowships. ${ }^{9}$ Candidates participating in the match are, in theory, not bound by job offers initiated prior to the resolution of the match - thus nullifying the power of exploding offers to constrain their choices. Employer participation in the match is voluntary, however, and the value of participation will depend positively on the fraction of competitors who are also participating.

A compelling feature of Niederle and Roth's quantitative case study of the gastroenterology (GI) market is that the profession adopted a centralized match in 1989 in response to widespread signs of market malfunction, but participation in the match began to decline after six years, and the match was formally abandoned in 2000. This set of events yields two pre-post contrasts for quantitative study, one prior to the match's adoption and the other subsequent to its demise. The available evidence suggests that the centralized match mitigated some clear market maladies, dramatically compressing the highly dispersed timing of job offers (which led to artificial thinness) and increasing the mobility of GI residents out of the hospitals where they performed their residences (suggesting that the match reduced monopsony power among incumbent employers). The chapter also examines the contentious question of whether the centralized match depressed fellowship salaries below competitive levels. Niederle and Roth find essentially no difference in salary levels between specialties that use a match and those

\footnotetext{
${ }^{9}$ As the chapter discusses, the results of such a match are stable — that is, there exists no applicantemployer pair, not matched to one another, who would prefer each other to their current match. Moreover, it is generally (though not always) incentive-compatible for applicants to submit their true preferences to the clearinghouse.
} 
that do not, suggesting that centralized matching does not dampen salaries per se. Equally remarkable, however, is that the data reveal almost no economically significant variation in fellowship salary levels or dispersion across the 14 specialties considered. This absence of variation raises the question of whether, in addition to congestion, the maladies of the fellowship market are in part explained by other non-competitive factors.

The GI matching market example underscores the potential of a Labor Market Intermediary to resolve collective action problems, in this case, restraining employers from making early offers. The demise of the GI match in 2000, however, suggests that something was amiss. Niederle and Roth trace the breakdown of the match to a sudden and substantial falloff in the supply of GI fellows spurred by a policy change by the Gastroenterology Leadership Council. When in 1996, the number of fellows fell below the number of available fellowship slots, the temptation for employers to circumvent the match to guarantee their supply of labor may simply have become overwhelming. And because employer participation in the match was voluntary, the matching intermediary had no teeth with which to discipline defectors. The match therefore unraveled as initial defections spurred further defections, rendering the match irrelevant by 2000. The GI case again underscores that the ability to compel participation by at least one side of the market - and perhaps by both-is a necessary requirement for an LMI to redress a market failure, in this case, a collective action failure. The GI fellowship match appears to have had this power when the labor market was slack, but not when it was tight.

The Freeman and Rehavi chapter, which offers an innovative study of the changing shape of labor unions, provides a compelling point of comparison to the GI case. While the National Resident Matching Program is an LMI with the power to change market payoffs (at least some of the time), labor unions are an LMI adapting to the loss of this power. Unions have historically solved collective action problems among atomistic workers by organizing collective bargaining, sanctioning employers for misconduct, and regulating employers' hiring and dismissal policies. A key to their ability to perform this function in the United States is the National Labor Relations Act of 1935, which compels employers to bargain collectively with a labor union if a majority of the firm's employees votes for union representation. Thus, once a union is established, it holds an effective monopoly on bargaining. 
While survey evidence suggests that worker demand for union representation has increased with time, union density in the US has fallen to almost negligible levels (7.4 percent in 2006). Labor unions have also lost their efficacy in the UK, where the range of issues subject to collective bargaining has narrowed. If unions can no longer generate sizable member benefits, their ability to build membership and levy dues diminishes, reducing their power further. This threatens their viability as an LMI.

Against this backdrop, Freeman and Rehavi study an alternative organizing model for unions, which they refer to as 'open source.’ In the open source model, unions are decoupled from workplaces and do not collectively bargain. They attract members by offering a package of services such as legal advice, group employment benefits (e.g., health insurance), and political lobbying on labor issues. Two features of this open source model represent a radical departure from the traditional labor union mode. First, open source unions lack what is certainly the most effective tool that traditional unions possessed for generating member benefits: collective bargaining. Second, many of the services that open source unions will purportedly provide, such as lobbying, are nonexcludable public goods. This leaves them highly vulnerable to free-riding, which was essentially impossible when union membership and compulsory dues-paying were preconditions for participation in collective bargaining. This 'open source' model will sharply limit the membership fees that such unions can charge.

Despite these threats, Freeman and Rehavi see reasons for tempered optimism about unions' prospects in the current era. A first is that the Internet has greatly augmented the capability of unions to communicate with potential members outside of the workplace, and at much lower cost than door-to-door canvassing. Moreover, the set of union services that can be provided over the Internet has proven to extend beyond mere online replication of traditional direct-mail and fundraising operations. Freeman and Rehavi's innovative analysis of question-and-answer postings ('threads') on the website of unionreps.org provides a compelling example of a union successfully using the Internet to provide a set of tangible, individual-level member services, most importantly, legal advice on workplace matters.

As another example, Freeman and Rehavi consider the success of a non-workplacebased union, Working America (a "community-affiliate” of the AFL-CIO union), which 
enrolled two million workers between 2004 and 2007 by canvassing at homes and over the Internet. Working America's success in drawing membership suggests, consistent with survey evidence, that there is considerable latent demand for organized labor as a political movement. Working America’s direct membership benefits are, however, quite limited relative to a traditional labor union, and its fee structure is accordingly modest.

If unions are successful in reconstituting under the 'open source' model, my expectation is that this will reflect a profound change in their core function as Labor Market Intermediaries. Whereas traditional labor unions primarily served, in the taxonomy of this chapter, as enforcers of collective action, 'open source' unions appear poised to serve primarily as information-provision intermediaries-more akin to job boards than to the medical match studied by Niederle and Roth. Thus, if the power to compel participation is the sine qua non of LMIs that move the market equilibrium, the potential of open source unions to generate worker benefits that approach that of unions of an earlier era is likely to be limited.

\section{Temporary help agencies: What do they do for workers? What do they do to the labor market?}

More than any other Labor Market Intermediary, the temporary help industry has been the subject of intensive recent debate. This is in part due to its spectacular growth. In the U.S., the temporary help industry accounted for 10 percent of net job creation during the decade of the 1990s (Autor 2003). In continental Europe and the United Kingdom, temporary help agency employment increased its share of average daily employment from 1.0 to 1.8 percent between 1986 and 1996. In the same interval, the number of workers employed by temporary help agencies more than tripled in Germany, Denmark and Ireland. In Japan, temporary help employment grew four-fold following significant deregulation (CIETT 2007).

Accompanying the growth of temporary help employment has been a qualitative change in the type of jobs filled by temporary help agencies. Historically, temporary help agency jobs were synonymous with clerical and office work. By 2005, a larger share of temporary help jobs in the U.S. was found in production, transportation, and material 
moving jobs than in clerical or sales occupations. ${ }^{10}$ As temporary help jobs have moved into blue-collar occupations, the industry has become an increasingly important employer of less-skilled workers. Although it accounts for less than 3 percent of average US daily employment, U.S. state administrative data show that 15 to 40 percent of former welfare recipients who obtained employment in the years following the 1996 US welfare reform took jobs in the temporary help sector (Autor and Houseman 2005). Alongside their traditional role of filling short-term staffing needs, temporary help jobs are increasingly used by employers to screen workers for direct-hire positions at arm's length ('temp-tohire') without the attendant risk of litigation should the match end badly.

The rapid growth of temporary help employment among low-skilled workers and the increasing prevalence of temp-to-perm arrangements has spurred an academic and policy debate as to whether temporary help jobs facilitate or hinder labor market advancement of job-seekers. Numerous researchers have hypothesized that stints in temporary help employment enable workers to develop skills and contacts that eventually lead to stable, long-term employment. Moreover, because temporary help firms face uniquely low marginal costs of hiring and firing, these firms may be willing to 'audition' candidates who would otherwise have difficulty finding direct-hire jobs (Abraham 1988; Katz and Krueger 1999; Autor 2001a and 2003; Houseman 2001; Autor and Houseman 2002; Houseman, Kalleberg, and Erickcek 2003; Kalleberg, Reynolds, and Marsden 2003). But these hypothesized benefits are uncertain. Scholars and practitioners have also argued that the unstable and primarily low-skilled positions available through temporary help agencies provide little opportunity for workers to develop human capital or engage in productive job search (Parker 1994; Pawasarat 1997; Jorgenson and Riemer 2000; Benner, Leete and Pastor 2007). If spells with temporary help agencies also inhibit workers from engaging in productive job search—after all, job search takes timetemporary help employment might hinder workers from obtaining stable jobs.

Distinguishing among these competing hypotheses is a significant empirical challenge. It is inherently difficult to differentiate the effects of holding given job types from the skills and motivations that cause workers to hold these jobs initially. Four

\footnotetext{
${ }^{10}$ Bureau of Labor Statistics, http://www.bls.gov/news.release/conemp.toc.htm, accessed 1/20/2008 (based upon Current Population Survey February 2005 Contingent Worker Supplement).
} 
chapters in this volume take steps in this direction, however, by studying the role that temporary help jobs play in the labor market advancement of job-seekers in Portugal, Germany, and the United States.

Before discussing the findings of these chapters, it is useful to consider the temporary help industry through the conceptual lens applied to other LMIs - that is, as institutions that potentially redress market imperfections arising from decentralized job matching between workers and firms. The market imperfection to which temporary help firms primarily address themselves is the fixed cost of job search. Identifying, screening and hiring workers is a fixed cost that must be sunk before actual paid work gets done. This cost may not be worth sinking if the job to be filled is brief or has a short shelf life, e.g., substituting for an employee who falls ill for a week. Temporary help firms sink these fixed costs up front by pre-screening workers and clients. They defray these sunk costs by introducing a wedge between the hourly wage billed to the client firm and the hourly wage (and other payroll costs) paid to the temporary worker.

Unlike most of the LMIs considered above, temporary help agencies function on a two-sided voluntary participation model; neither workers nor firms are obliged to use their services unless they see gains from doing so. From the firm's perspective, the gain to temporary help arrangements is that they convert their fixed job search costs into marginal costs by providing a supply of pre-screened workers who are waiting at the gate. From the job-seeker’s perspective, temporary help agencies potentially offer immediate short-term, hourly employment with almost no initial, fixed investment in job search. ${ }^{11}$ In addition, temporary help arrangements facilitate arms length screening by allowing firms to audition workers without the attendant fixed costs of hiring and the legal risks of firing. The possibility of a 'temp-to-perm' transition also makes temporary

\footnotetext{
${ }^{11}$ Why, given these efficiencies, are the majority of jobs not found through temporary help firms? A likely answer is that, due to their informational advantage on both the supply and demand side of the labor market, temporary help firms find it optimal to charge a relatively high markup on their services. This markup, estimated at 40 to 60 percentage points above the hourly wage paid to the worker (Autor, Levy and Murnane 1999), provides workers and firms with an incentive to circumvent temporary-help arrangements for longer-term matches. Similarly to mortgage brokers and for-profit employment agencies, temporary-help agencies hold an informational advantage relative to their clients, and, as seen in other examples, this gives rise to its own difficulties-here, monopsonistic pricing.
} 
help positions more attractive to workers, many of whom report using temporary help as a means of job search (Autor 2001a).

These observations—in particular, the fact that temporary help agencies rely on voluntary two-sided participation—immediately suggests that their potential to substantially change labor market outcomes for individual workers or firms is likely to be limited; if this were not so, these arrangements would either be much less common or much more prevalent. This does not imply that temporary help firms neither help nor harm workers (or firms) at the margin. Indeed, Autor and Houseman (2005) provide quasi-experimental evidence that low-skilled former welfare recipients in the U.S. placed in temporary help agency jobs receive no lasting earnings or employment benefits from these placements, whereas ex ante identical individuals placed in direct-hire positions accrue substantial earnings gains over the course of two to three years following placement. Nevertheless, if temporary help agency employment exists in equilibrium alongside other employment forms, it is unlikely that temporary help jobs are either strictly dominant or strictly dominated by either employment arrangements.

The evidence presented in the final four chapters of the volume appears to corroborate this reasoning, though with many important nuances. The study by René Böheim and Ana Rute Cardoso uses uniquely detailed, linked worker-firm data from Portugal to analyze whether workers suffer a wage penalty either while working for temporary help firms or in the two years following entry into temporary help employment. As a descriptive matter, their analysis confirms that workers in temporary help jobs earn about 10 percent less than observationally similar workers in nontemporary help ('direct-hire') jobs. But once person fixed-effects are included to account for unobserved worker heterogeneity, this wage penalty disappears or becomes positive. These results imply that there is negative self-selection of workers into temporary help jobs in Portugal, a pattern also documented for the United States (Segal and Sullivan, 1997). ${ }^{12}$

\footnotetext{
${ }^{12}$ Böheim and Cardoso also estimate that workers who have previously held a temporary-help job suffer no measurable wage penalty when entering direct-hire employment. Interpretation of this result deserves particular caution, however, since the analysis is conditioned on remaining in employment (wages are not otherwise observed).
} 
While Böheim and Cardoso focus primarily on earnings in temporary help jobs, the chapters by Carolyn Heinrich, Peter Muesuer and Kenneth Troske, Frederick Andersson, Harry Holzer and Julia Lane, and Michael Kvasnika study the question of whether temporary help jobs augment or inhibit labor market advancement over the longer-term. Using employment register data from Germany, Kvasnicka analyzes whether unemployed job-seekers who take temporary help jobs are more likely to later obtain direct-hire employment than observationally similar workers who do not take temporary help jobs. The analytical tool used in this study is a matching estimator, which identifies pairs of workers who are observationally similar up to the point where one member of the pair obtains a temporary help job. From this point of divergence forward, the estimator compares the trajectory of the two workers to estimate of the impact of temporary help employment on the 'treated' relative to the 'non-treated' worker over the subsequent four years.

Contrary to many studies of temporary help employment in European countries, Kvasnicka's analysis finds no evidence that temporary help employment increases jobtakers' subsequent rate of direct-hire employment over four years. However, the data clearly show that workers who enter temporary help employment from unemployment are substantially more likely to remain in temporary help jobs over the subsequent four years. Kvasnicka concludes that temporary help jobs increase workers’ employment and earnings in the temporary help sector without causing any crowd-out of their advancement into direct-hire employment. As with all studies based on observational (i.e., non-experimental) data, one must also consider the possibility that the results are in part driven by unobserved differences in skills and motivations among different groups of workers. Ultimately, the validity of this approach hinges on the assumption that the treatment variable (temporary help job employment) can be treated as randomly assigned conditional on the observable variables used for the matching estimator.

Similar in spirit to the Böheim and Cardoso study, the chapter by Andersson, Holzer and Lane estimates a model of worker earnings that includes both worker and firm fixed effects. Distinct from Böheim and Cardoso, the fixed effects model in this chapter draws on earnings data from an earlier time period, thus making the fixed-effect more akin to a measure of workers’ permanent earnings and firms’ average salaries than a conventional 
fixed-effects estimator. A particular strength of the Andersson et al. chapter is its rigorous analysis of the trajectory of employment by sector. The chapter explores not only whether workers in temporary help jobs later obtain direct-hire employment, but also whether these jobs are found in high wage industries and with high wage employers. The key result of this analysis is that, although workers earn comparatively low wages while in temporary help jobs, their subsequent earnings are often relatively high—but only if they succeed in gaining stable work with direct-hire employers. Consistent with the view that selective firms use temporary help arrangements to screen workers for desirable directhire jobs, the chapter documents that temporary help workers who successfully transition to stable, direct-hire employment often end up employed by relatively high wage firms.

A question left open in part by the Andersson et al. chapter is the role played by worker heterogeneity. In particular, for workers who successfully transition from temporary help employment to stable, direct-hire jobs, it is difficult to know whether their spells in temporary help employment were the cause of these successful transitions or primarily a waypoint on the route that these workers were navigating. The chapter by Heinrich, Mueser and Troske makes an ambitious effort to assess the importance of selfselection in this context, drawing on recent econometric techniques developed by Altonji, Elder and Taber (2005). Altonji et al. argue that it is feasible to assess the likely extent of bias stemming from self-selection on unobserved variables by measuring the extent of self-selection on observed variables. The key to their approach is the maintained hypothesis that self-selection on observables and unobservables is positively correlated. Concretely, imagine that in estimating the effect of temporary help employment on subsequent employment outcomes, a researcher finds that including a worker's educational attainment in the statistical model leads to a substantial increase in the estimated benefits from temporary help employment. This pattern would indicate that there is significant negative self-selection into temporary help employment based on education (an observable variable). ${ }^{13}$ Under the assumptions of the Altonji et al. framework, this would further imply that selection on unobserved variables, such as

\footnotetext{
${ }^{13}$ Specifically, we take as given that education is strongly positively correlated with earnings and other positive labor market outcomes. If adding education to a wage regression raises the coefficient on temporary-help employment, this implies that temporary-help employment and education are negatively correlated, i.e., there is negative self-selection into temporary-help employment based on education.
} 
latent human capital or taste for effort, is also likely to be important. By contrast, if the estimates were found to be largely invariant to the exclusion of all subsets of observable variables, this would serve as evidence that self-selection on unobservables is unlikely to be important.

Heinrich et al. put these ideas into practice by studying the employment and earnings trajectories of individuals in the state of Missouri who sought employment assistance or cash support through one of several federal assistance programs. Consistent with prior research by the authors (Heinrich et al., 2005), they document that the temporary help industry plays a uniquely important role as a transitional source of employment for lowskilled job-seekers. A key finding of their chapter is that stints in temporary help employment have little measurable effect on subsequent earnings or employment. Yet, consistent with Andersson et al., Heinrich et al. observe that successful transitions from the temporary help sector are critical to workers' labor market advancement; workers who remain in temporary help employment experience long-run earnings that are substantially below those of workers in other sectors.

A major contribution of the Heinrich et al. chapter is their application of the Altonji et al. method to assess the likelihood that the causal effects estimated from the observational data are spurious. This analysis presents a nuanced picture. For earnings, the Altonji et al. test is frequently consistent with the null hypothesis that the causal effects estimates are not spurious. For employment, this is less often the case. Though these results present a somewhat ambiguous picture, one cannot fail to be impressed by the rigor, clarity and intellectual candor of the Heinrich et al. analysis. Economic knowledge and credibility would be well served if more researchers subjected their findings to equally rigorous sensitivity testing.

In net, these four chapters, using disparate data sources from three different industrialized economies, have a clear commonality of conclusions. None suggests that temporary help jobs have any lasting negative effect on the workers who obtain them. Whether holding these jobs has positive effects on worker outcomes relative to what they would have obtained in the absence of temporary help employment is less certain. As a descriptive matter, many temporary help workers transition from temporary help to direct-hire jobs at higher wages. Simultaneously, those who stay behind fare relatively 
poorly. It is a certainty that those who stay behind over the longer term are on average adversely selected — that is, their unobserved skills or motivation put them at a disadvantage relative to other workers. By the same token, those who leave temporary help employment for higher-paying and more durable direct-hire positions are likely positively selected. These countervailing forces of selection make it difficult to conclude with certainty if the causal effect of temporary help employment is positive, or merely neutral, for the subset of workers making successful transitions from temporary help to direct-hire employment.

This set of findings suggest a relatively benign labor market role for temporary help agencies. Yet, there exists substantial suspicion among policymakers and social scientists (particularly outside of economics) that temporary help jobs are exploitative, offering below-market pay and limited opportunities for advancement. From whence does this suspicion arise? One possibility is that because temporary help agencies are for-profit LMIs - unlike, for example, labor unions, public employment agencies, or university job placement consortia - they face a pecuniary incentive to minimize wages and benefits, and to inhibit workers from obtaining other, potentially superior, positions. In this respect, however, temporary help agencies appear no different from other employers, and so it is hard to credit this viewpoint.

Perhaps a more compelling argument is that widespread use of temporary help agencies, even if beneficial to individual workers and firms, may exert a negative externality on the aggregate labor market— that is, it is a 'public bad.' One case in point for this argument is that temporary-agency workers cannot vote in union certification elections at client firms since, for legal purposes, the temporary help agency is their employer of record. Moreover, temporary help workers are nearly impossible to organize at their temporary help agency offices since they do not perform work at these sites. Temporary help arrangements may therefore inhibit collective action that would otherwise benefit workers. Indeed, anecdotal evidence suggests that some firms use temporary help agencies to illegally screen out potential union organizers. ${ }^{14}$

\footnotetext{
${ }^{14}$ Reflecting the natural tensions between temporary help agencies and labor unions, Houseman, Kalleberg and Erickcek (2003) document specific union prohibitions on the use of temporary help agency workers at the auto parts manufacturers and hospitals that they study.
} 
More broadly, some scholars have argued that the availability of temporary help agencies encourages employers to pursue a high turnover, low skill-investment human resources strategy (see, in particular, Benner, Leete and Pastor 2007, chapters 1 and 6). Were the LMI of temporary help unavailable, this argument suggests that employers would offer better job opportunities with greater opportunities for skill acquisition and labor market advancement. ${ }^{15}$

Because they operate exclusively at the general equilibrium, macroeconomic level, these hypotheses are extremely difficult to test-even more so than person-level effects of temporary help employment studied by the four chapters in the volume. Moreover, alongside these arguments, one must alternatively consider that temporary help agencies may increase aggregate labor market efficiency and reduce unemployment by diminishing the time workers and firms spend in unproductive search (Katz and Krueger 1999). ${ }^{16}$ At this point, one can only confidently state that the question of how temporary help employment affects aggregate labor market efficiency and the quality of jobs available in general equilibrium is of first-order importance. A compelling answer to this question, however, awaits a suitably ingenious research design.

\section{Conclusions}

The labor market depicted by undergraduate textbooks is a pure spot market, characterized by complete information and atomistic price-taking. Labor economists have long understood that this model is highly incomplete. Search is costly, information is typically imperfect and often asymmetric, firms are not always price takers, and atomistic actors are typically unable to resolve coordination and collective action failures. In this 'second-best of all worlds,' there is scope for third parties to intercede, both to improve the operation of the labor market and to profit from its imperfections.

One might have speculated, however, that in an era of rapid information flows and substantial job mobility, the importance of labor market intermediaries would wane.

\footnotetext{
${ }^{15}$ Kaushik Basu (2003) provides a rigorous discussion of how laissez-faire bargaining among competitive workers and firms over the terms of employment can result in a market equilibrium that is not necessarily socially desirable.

${ }^{16}$ This positive aggregate benefit, if present, does not preclude the possibility that individual workers who use temporary-help agencies fare worse on average than those who do not; that is, the public good and the private good may have countervailing effects on individuals, even if the public good dominates on average.
} 
Indeed, the most prominent LMI, the traditional labor union, has been in secular declines for decades. Yet, the decline of labor unions as an LMI is the exception rather than the rule. Three of the LMIs studied in this volume-online search engines, criminal records providers and open-source unions - have only recently emerged. And a fourth, temporary help agencies, has risen from relative obscurity to international prominence over the last two decades.

Though recent technological advances have made market information more abundant and less expensive, cheap information alone is rarely sufficient to solve the fundamental problems posed by costly and asymmetric information, adverse selection, and failures of collective action. ${ }^{17}$ Ultimately, the imperfections endemic to decentralized labor markets generate demand for institutions that can variously compel disclosure of hidden information, coordinate the actions of members of a congested market, or solve collective action failures among parties with complementary interests. The Labor Market Intermediaries studied in this volume perform these functions, though always imperfectly, and not without attendant costs and abuses. Despite widely heralded advances in the technology of job matching, it is my strong contention that Labor Market Intermediaries will continue to arise to address, ameliorate, and exploit the imperfect environment in which workers and employers interact.

\footnotetext{
${ }^{17}$ Indeed, cheap information can in some cases exacerbate adverse selection by eliminating the signaling value of formerly costly actions such as submitting job applications (Autor 2001b).
} 


\section{References}

Abraham, Katharine G. 1988. "Flexible Staffing Arrangements and Employers' Shortterm Adjustment Strategies.” In Employment, Unemployment, and Labor Utilization, Robert A. Hart, ed. Boston: Unwin Hyman.

Akerlof, George A. 1970. “The Market for 'Lemons:' Quality, Uncertainty and the Market Mechanism.” Quarterly Journal of Economics, 84(3), August, 488-500.

Altonji, Joseph G., Todd E. Elder and Christopher R. Taber. 2005. "Selection on Observed and Unobserved Variables: Assessing the Effectiveness of Catholic Schools.” Journal of Political Economy, 113(1), 151-184.

Autor, David. 2001a. "Why do Temporary Help Firms Provide Free General Skills Training?” 2001. Quarterly Journal of Economics, 116 (4), November, 1409-1448.

Autor, David. 2001b. “Wiring the Labor Market.” Journal of Economic Perspectives, 15(1), Winter, 25 - 40.

Autor, David. 2003. "Outsourcing at Will: The Contribution of Unjust Dismissal Doctrine to the Growth of Employment Outsourcing." 2003. Journal of Labor Economics, 21(1), January, $1-42$.

Autor, David, Frank Levy and Richard J. Murnane. 1999. "Skills Training in the Temporary Help Sector: Employer Motivations and Worker Impacts.” MIT Mimeograph, September.

Autor, David and Susan N. Houseman. 2002. “The Role of Temporary Employment Agencies in Welfare to Work: Part of the Problem or Part of the Solution?” Focus 22(1): 63-70.

Autor, David and Susan N. Houseman. 2005. "Do Temporary Help Jobs Improve Labor Market Outcomes for Low-Skilled Workers? Evidence from Random Assignments.” NBER Working Paper No. 11743, November.

Basu, Kaushik. 2003. "The Economics and Law of Sexual Harassment in the Workplace.” Journal of Economic Perspectives. 17(3), Summer, 141-157.

Benner, Chris, Laura Leete and Manuel Pastor. 2007. Staircases or Treadmills? Labor Market Intermediaries and Economic Opportunity in a Changing Economy. New York: Russell Sage Foundation.

CIETT (International Confederation of Private Employment Agencies). 2007. "The Agency Work Industry around the World”. http://www.ciett.org/fileadmin/templates/ciett/docs/Ciett_Economic_Report_2007.pd f, accessed 9/2/2008.

Diamond, Peter A. 1982. "Wage Determination and Efficiency in Search Equilibrium." Review of Economic Studies, 49, 217-227. 
Friedman, Milton. 1962. Capitalism and Freedom. University of Chicago Press, Chicago.

Heinrich, Carolyn J., Peter R. Mueser, and Kenneth R. Troske. 2005. "Welfare to Temporary Work: Implications for Labor Market Outcomes.” Review of Economics and Statistics 87(1): 154-173.

Houseman, Susan N. 2001. "Why Employers Use Flexible Staffing Arrangements: Evidence from an Establishment Survey.” Industrial and Labor Relations Review 55(1): 149-170.

Houseman, Susan N., Arne J. Kalleberg, and George A. Erickcek. 2003. "The Role of Temporary Help Employment in Tight Labor Markets.” Industrial and Labor Relations Review 57(1): 105--127.

Jorgenson, Helene, and Hans Riemer. 2000. "Permatemps: Young Temp Workers as Permanent Second Class Employees.” American Prospect 11(18): 38--40.

Kalleberg, Arne L., Jeremy Reynolds, and Peter V. Marsden. 2003. "Externalizing Employment: Flexible Staffing Arrangements in U.S. Organizations.” Social Science Research 32: 525-552.

Katz, Lawrence F., and Alan B. Krueger. 1999. "The High-Pressure U.S. Labor Market of the 1990s.” Brookings Papers on Economic Activity 0(1): 1-65.

Katz, Lawrence F. and Lawrence H. Summers. 1989. "Industry Rents: Evidence and Implications.” Brookings Papers on Economic Activity: Microeconomics, 209-290.

Kleiner, Morris M. 2006. "Licensing Occupations: Ensuring Quality or Restricting Competition?” Kalamazoo: W.E. Upjohn Institute for Employment Research.

Kroft, Kory and Devin G Pope. 2007. "The Effect of the Internet on Matching Markets: Evidence from Craigslist," Wharton School mimeograph, November.

Krueger, Alan B. and Lawrence H. Summers. 1988. "Efficiency Wages and the Interindustry Wage Structure.” Econometrica, 56(2), 259-293.

Kuhn, Peter, and Mikal Skuterud. 2004. "Internet Job Search and Unemployment Durations.” American Economic Review, 94(1), 218-232.

Kugler, Adriana and Gilles Saint-Paul. 2004. "How do Firing Costs Affect Worker Flows in a World with Adverse Selection?” Journal of Labor Economics, 22(3), 553-584.

Lewis, H.G. (1986) Union Relative Wage Effects. Chicago: University of Chicago Press.

Mortensen, Dale T. 1982. "The Matching Process as a Non-Cooperative Bargaining Game,” in J.J. McCall (ed.), The Economics of Information and Uncertainty, Chicago: University of Chicago Press.

Parker, Robert E. 1994. Flesh Peddlers and Warm Bodies: The Temporary Help Industry and Its Workers. New York: Rutgers University Press. 
Pawasarat, John. 1997. "The Employer Perspective: Jobs Held by the Milwaukee County AFDC Single Parent Population (January 1996-March 1997).” Milwaukee: Employment and Training Institute, University of Wisconsin-Milwaukee.

Pissarides, Chris A. 1986. “Unemployment and Vacancies in Britain.” Economic Policy, 3, 499-559.

Segal, Lewis M., and Daniel G. Sullivan. 1997. "The Growth of Temporary Services Work.” Journal of Economic Perspectives, 11, 117--136.

Slichter, Sumner. 1950. "Notes on the Structure of Wages," Review of Economics and Statistics 32, 80-91.

Spence, Michael. 1973 “Job Market Signaling,” Quarterly Journal of Economics, 87(3), August, 355-374. 
Table 1.

Market Failure

\begin{tabular}{cccc} 
& Worker- & & \\
Information & Side & Firm-Side & Coordination \\
Provision/ & Adverse & Adverse & \& Collective \\
Search Costs & Selection & Selection & Action \\
\hline
\end{tabular}

Traditional job

boards

Comprehensive

job boards (e.g.,

AlmaLaurea)

Criminal records

providers

Public

employment

offices

Labor standards

regulations

Centralized

medical job match

Labor unions

Temporary help

agencies
Nature of Participation

$\begin{array}{ccc}\text { Voluntary for } & \text { Voluntary for } & \text { Voluntary for } \\ \text { Workers and } & \text { Firms not } \\ \text { Firms } & \text { Workers } & \text { Workers not } \\ & \text { Firms }\end{array}$

